\title{
Muséologies
}

Les cahiers d'études supérieures

\section{Social Practice as Gallery Programming: An Interview with Sarah Febbraro}

\section{Natasha S. Reid}

Volume 7, numéro 1, 2014

Le dialogue dans les musées d’art contemporain

URI : https://id.erudit.org/iderudit/1026652ar

DOI : https://doi.org/10.7202/1026652ar

Aller au sommaire du numéro

Éditeur(s)

Association Québécoise de Promotion des Recherches Étudiantes en Muséologie (AQPREM)

ISSN

1718-5181 (imprimé)

1929-7815 (numérique)

Découvrir la revue

Citer ce document

Reid, N. S. (2014). Social Practice as Gallery Programming: An Interview with Sarah Febbraro. Muséologies, 7(1), 159-166. https://doi.org/10.7202/1026652ar

Tous droits réservés (C Association Québécoise de Promotion des Recherches Étudiantes en Muséologie (AQPREM), 2014
Ce document est protégé par la loi sur le droit d'auteur. L'utilisation des services d'Érudit (y compris la reproduction) est assujettie à sa politique d'utilisation que vous pouvez consulter en ligne.

https://apropos.erudit.org/fr/usagers/politique-dutilisation/ 
Entrevue un

\section{Social Practice as Gallery Programming: An Interview with Sarah Febbraro}

Natasha S. Reid 
Community outreach initiatives have played an important role in museums' social inclusion efforts. What types of relationships these outreach initiatives encourage, or should encourage, is an active and ongoing discourse, one that often calls for more in-depth, dialogue-driven relationships. In this effort, museums can turn to contemporary artists working with social practice, who focus on collaborative and participatory approaches where dialogue is considered to be central to their artistic endeavours. These artists often blur the boundaries between public and private and frequently work outside of the traditional museum or gallery setting. The Oakville Galleries have incorporated contemporary social practice in their outreach initiatives by engaging artist Sarah Febrraro as a community programmer. I had the privilege to speak with Febbraro, whose work is grounded in social practice, about the ways in which her artistic practices interconnect and overlap with her community programming work. The discussion is a deeply inspiring look at how contemporary art practices based in dialogic encounters can positively contribute to museums' efforts to reach out to diverse audiences in more meaningful ways. 


\section{Natasha S. Reid: Could you start by giving me an overview of what brought you to your current position?}

Sarah Febbraro: I finished my MFA in Chicago. My background experience is as a choreographer, a dancer; then I switched out of dance and went more into performance, but it really became about creating situations. It led me to community. I kind of got bored of performing, myself; that led to me providing a platform for other people. I was doing community projects without knowing the field of social practice. And then once I went to Chicago, there were tons of things going on there; there's a major history of grassroots movements in Chicago. And I met a lot of people who were doing great stuff. It totally helped me shape my practice. I was also connected to people in sculpture and fibers who were working with experimental art practices. I was always kind of an art educator or doing community art projects or working for community organizations that were doing art projects. I worked in Chicago with this organization called Urban Gateways; they put you in schools or community centers or churches: all different settings. I was the artist who was engaged to create these situations all across the city. Then I taught media to youth in various different community centres in lower income communities in Chicago. When I came here to Toronto, I worked for Arts for Children and Youth. And then I started connecting more to museum culture and to contemporary art practices, because I wanted to do more in the style of my own art projects.

I was introduced to Catherine Sicot, former Director of Public Programs and Education at Oakville Galleries. She had just received an Ontario Trillium Foundation grant, for the gallery to hire a community artist for three years. So I really came in at the right time [as the community programmer]. That position felt like it was made for me, even though I really didn't have any arts administration experience. I felt lucky, jumping right into a programming position. They really wanted to work with my sensibility and the way I thought about things. My art practice was what situated me and what they valued. They value ideas. So I had, in this way, free reign; the program never existed before.

It was four days a week. I knew that it was a hardcore job and I had never done arts administration or worked in a museum before. That was confusing as an artist, but I also knew that I was ready to develop myself professionally and to stay in one community for three years really interested me, as well as the type of work I could accomplish during that time.

This job was about creating a connection to the local communityreally serving. I was going to where people are rather than expecting people to come to the museum. It was a privileged position to be in, because there was not the pressure about how many people you get through the door at the museum. My program was really about going to audiences, not bringing them back. I had no pressure to do that, whereas the art educator does. 


\section{$\mathrm{N}$ : So you never brought the community into the gallery?}

S: The whole grant was based on off-site work. I mean, I started a youth council that met there every week and they had an exhibition there every year. That was a big thing. And then a couple of our programs were tours of the exhibitions or picnics in the gardens. But in general, it was about going off-site and just acknowledging that there are different models and methods to connect to people. So it is not about bringing them back and connecting them to an exhibition. But if it happened, okay.

\section{$\mathrm{N}$ : So the programming you were doing, it did not necessarily have to connect to what was going on inside the gallery?}

S: Not at all. My priority was about using contemporary art as a tool to connect to communities throughout Oakville. My projects had to be informed by contemporary art practices but they often said, "We trust your ideas and your methods for generating the projects".

\section{$\mathrm{N}$ : What types of publics were you reaching out to?}

S: The grant was to reach seniors, adults with disabilities, youth, new generation Canadians, and also, if there was time, to bridge the gap between the local craft community or the local art community and the contemporary art museum. We are in a heritage house. We have two locations. One location is a house that was owned by this general who, when he died, wanted it to be left to the art community. All of the local artists used to have studios at the house. Then it was taken over by Oakville Galleries. Basically, once it became a contemporary art museum, and became kind of an international fixture, it wasn't a space for local artists to showcase their work or have a studio at all. In the eyes of many Oakville artists, it became an elitist place. There had been a real gap [with the community], so my projects were about rebuilding that relationship. I think the projects we did helped a lot. It was intense. I realized that instead of doing a billion different things, it's good to focus and try to have some sustainable projects that can grow and be passed on to other organizations to continue.

\section{$\mathrm{N}$ : Your role was to also make those connections with the com- munity more diverse and sustainable.}

S: Yes, and to really build relationships with the local communities. Which I think the programs did, for sure. The education department totally does that as well. But, my programs were free-totally free. So, we were really trying to reach lower income families, marginalized communities. We wanted to make it easy for them to do a project. That's why, in terms of mobility, I would go to senior's residences and to adults with disabilities. We would work with the partner organizations and collaborate. So it wasn't like I was imposing our idea on a community that I didn't have a relationship with for the sake of the museum. That is why I feel very privileged-because it was really about the community. 


\section{$\mathrm{N}$ : What role did contemporary art play in this type of relation- ship development in the community?}

S: I was thinking about that question, and at first I thought it didn't play that much of a role. Then I realized it did, because it shaped my whole practice and my way of seeing things. Contemporary art allowed me to merge different fields of knowledge. Social practice, or what I call socially-engaged art, is really about a merging of art education, social sciences, and different fields of knowledge. It is interdisciplinary. I think the current model for contemporary art-because it is about a blurring of those roles between programmer and artist, and curator and artist, and art education and so on-allowed for me to step into a programming position without any programming experience, because of my art practice, and for me to think about programs the way I think about art. Without being an artist, I think my programs would be very different. I was able to invent models for community development based on everyday life - that connection to everyday life and how contemporary art values that. For me, talking and hanging out is a big part of my art practice. It was really about building community for me. It was very close [to my artistic practice] and at the same time, totally different. It was really, really interesting. It totally developed my art practice. There were so many crossovers.

\section{N: You said talking and hanging out is a big part of your art prac-} tice. That connects with the theme of this issue, which is the use of dialogue within the realm of contemporary art. It sounds like you were really drawing on this in your work at the Oakville Galleries. S: Oh, yes. Before I understood any kind of model or way of approaching community-I am just such a social person, so how I would partner with organizations was literally by just calling somebody up, going to the church or going to the community centre, meeting them, having a talk, seeing what they needed. It was very organic. So, it was all about talking. And the programming too: all about talking. There were projects where I would have to stop and ask what the participants wanted, and do talking exercises. I didn't know every single organization and we partnered with thirty. So, I obviously didn't pretend to be an expert in all those organizations. It was really about partnering with either the senior's recreation coordinator or the church outreach person or the community centre's youth worker-the people who know their field. I would be like, I know my field and you know your field. Because we were partnering, they got to have a program for free and I usually got a venue and a connection to an audience that I would not usually have a connection with. It wasn't random- these were very targeted audiences.

There are all these social art practices that create situations like "DJs with seniors". And, I was thinking, I bet these seniors don't even want to do that. So, I always did this card game. I would just basically hand out blank cards and I wrote down a list of questions as a conversation. In a previous program, we did a lecture series in the seniors' residence and I was just evaluating if they liked it, what kind of programs did they want to do, what is something that would never happen in their residence, what would be their dream to do if they could do it, what do they hate 
doing, what is stereotypical, and so on. So then we had an open conversation. I realized that so many of them have such rich histories. One thing that came across is that they wanted their stories to be recorded. Either they felt like they were at the end of their lives and they wanted a record made, or they wanted it at their funeral, or they wanted their grandkids to have it. For me, it was even bigger than that. So I created this whole project with the seniors' organization called the Portrait Projects. It didn't have a crazy spin on it. It was about going to a senior's apartment and hanging out with them for an hour. This used my skill set, since I'm all about talking and this was me hanging out with seniors in their apartments and facilitating a conversation with them-totally off the cuff, nothing set, for an hour. It was amazing. And then I gave each senior three DVD copies of the full footage of their interviews. At the end, I turned it into a documentary and it was screened at the seniors' residence. It was a massive success. There were three-hundred seniors there. It was very powerful. That just came out of talking to them. Later, the project was transformed into a summer long exhibition at Queen Elizabeth Cultural and Community Centre in Oakville.

And then I started a youth council based on other museum youth groups. When I first got to Oakville, there was a teen sitting in the corner of the museum. I thought, I have to connect to you. So I connected with her right away. I asked, "What do you want to do?". She said, "I want to start a youth council". So then I talked to the director. We said, yes, totally, let's start a youth-based art scene in Oakville. There really isn't much for them. I facilitated everything and structured everything, but the feeling was that the ideas came from them, everything came from them. So, it was about their ideas about what they wanted to do, which changed the way I work completely. It has really influenced me. Even an art project I recently proposed was about getting a group of young people together and asking to be a participant in something they want to do. Because I feel that it is never criticized. Artists just assume you want to participate in a particular event. I was really sensitive to that. Especially when you are working with newcomers or seniors or adults with disabilities. And then it is more of a collaboration. So, it definitely had that pedagogical model of skill sharing, breaking that hierarchy between teacher and class—-breaking down those traditional ideas.

\section{N: Did you choose to ever introduce contemporary art to the groups that you were working with?}

S: Yes!

\section{N: Did you find that particular pedagogical techniques or artistic approaches from your own practice helped to break down any barriers between these groups and contemporary art?}

S: For seniors, I was interested in them having an experience where contemporary art was already embedded in it. I did not care or even value if they understood whether it was art or not. They knew I was from a museum. Sometimes they would say: "Why is this relevant?" or "Why is this an art project?". And I would explain that to them then, 
but one on one, casually. Because seniors understand that their voices need to be heard is general - it is a given. Or gardening and giving food to a local community is totally understandable.

$\mathrm{N}$ : It is very interesting, because you weren't teaching them about contemporary art in a literal sense. But in a very touching kind of way, you were teaching them about contemporary art through their experiences.

S: For sure. It was all experiential.

\section{$\mathrm{N}$ : It is less intimidating for the participants.}

S: Yes. There is no reason for the participants to be intimidated. I am interested now in programming as my art practice-programming in non-institutional spaces. So, for example, programming within my neighbourhood. I am not always into an institution having ownership over my ideas but at the same time the institution gives you validity and power. So, I want to go back and forth working within and outside of institutions.

\section{$\mathrm{N}$ : Could you talk about your longer-term collaborations?}

S: Longer-term collaborations are more successful. The third year of my youth council program was amazing. We could do things that were just wild. Now they are all in university. They all left. We had no money to continue it, which broke my heart. That was something the museum wanted to keep. I couldn't financially sustain it. There were about 5 people who were there from the first year. It started with 10 , then it went to 20 , then it went back to 10 . And, I'd have to say, with 10 , you can do amazing things. They started to create museum exhibitions. They created the ideas and I helped facilitate them. They were awesome. The last one was called "Up All Night". It was about being up all night. It was super amazing; it really came from them. We had such a good relationship. I pushed them extremely hard. By the end, I would take them on trips to Toronto. I would say, "I'm going to take you to a psychic today". They also made up all the things they wanted to do. I would say, "Anything you want to do!" They would say things like, "Bring a stylist in". I would just set things up. It was very generated by them. I miss that. I loved them.

The seniors, too-we had an amazing long-term relationship. And the church and the garden. I had a few love affairs with a few organizations that were just awesome.

$\mathrm{N}$ : I noticed one aspect of the vision of the Oakville Galleries is to stimulate thought, to shift perspectives, to inspire engagement, and I can clearly see that your work contributed to that. I was wondering if there was ever a time when you saw a perspective shift in your work with a group of individuals.

S: Definitely with the youth council—the way they saw art totally changed. They went from doing oil painting in high school to being super critical. I took them to the AGO and the Power Plant. They were doing presentations on queer artists. That was just amazing. Also, I taught them about zines, and in grade 11 they were very into the ' 90 s riot grrrl 
scene. There was this whole return to the ' 90 s. They wanted to do a show on the ' 90 s, but we didn't have time. They said that when they had first worked with zines, they didn't really get how relevant it was. In grade 12, they wanted to do the whole zine project again, because all of a sudden, writing and speaking their minds was such a crucial thing for them. They were all activists by grade 12 . That was a huge shift. And just hearing my community partners talk about our relationship-they would always say "dialogic art", and that would really blow me away. Or things like "art as a tool". Especially one woman from the church we partnered with. She did a lot of research. She would give presentations, and that was really cool to see how she really understood it.

\section{$\mathrm{N}$ : I was wondering, the programming you were doing, did it ever touch on social justice issues?}

S: Well, civic action, for sure. Gardening was huge. Even the youth created their own cultural events in their own town because there had been nothing. I felt that was really critical. Also, the seniors had a local newspaper that they wanted to make bigger. I felt there was room for participants from different organizations to start programming their own projects. Any time when the participants started taking over and programming for themselves, that felt like a social justice effort. I moved away from the more typical social justice projects. I'm not an activist, I don't protest, but I feel that my work is politicized. I don't try to solve social issues. I don't feel like I have the tools to do that. But I work with people who have spent their whole lives trying to solve such issues with those tools. So I really know my own boundaries and my place in it. At first I did want to do that, but then I realized that's what partnership is about. I'm part of the solution, but I'm doing it in a microscopic level in my own way. That's how I program. I think the change is actual because those relationships are real. But it's on a small scale.

\section{N: What do you envision as the future of contemporary art and contemporary art galleries, particularly the Oakville Galleries, in society?}

S: I did really see the community programs being shifted into more communities having part-ownership in the museum. So they would participate in programs, but they would be programmers as well. It would be on-site. I am thinking of these open-sourced schools, where people from the community propose a course and then that course is taught in the museum, and it's all sharing, all skills-sharing. My vision is to use public programs to get people closer to the museum by still focusing on community-related topics - topics that are not necessarily connected to exhibitions, but with the community's actual programming — and then to locate these pubic programs on-site. 